Millatī, Journal of Islamic Studies and Humanities

Vol. 4, No. 1, Juni 2019: p. 99-116. DOI: 10.18326/mlt.v4i1. 99-116

p-ISSN : 2541-3627; e-ISSN 2540-9964

Website: http://millati.iainsalatiga.ac.id/index.php/millati/index

\title{
Fundamental Human Rights of Women: Islamic Panacea for Rights Abuses
}

\author{
Rafatu Abdul Hamid \\ Faculty of Arts, Department of Philosophy and Religions, University of Abuja, Nigeria \\ rafatu.abdulbamid@uniabuja.edu.ng
}

\begin{abstract}
Fundamental human rights provisions had continued to feature very prominently in the successive constitutions of the Federal Republic of Nigeria. In addition, there had been a rise in the activities of human right groups in Nigeria in order to ensure the protection of fundamental human rights of all people. Despite all these, women fundamental human rights abuse was on the increase in Nigeria. The case of domestic violence, kidnapping, sexual harassment, women trafficking, killings, denial of the right to Education etc, are common occurrences. These abuses among others are responsible for physical and psychological underdevelopment of women and girl child which in turn affects their input in the development of their nation. It is against this backdrop that this paper examines two abuses of women fundamental human rights: abuse of right to life and education. The paper also discusses the instrumentality of effective use of the Islamic panacea in tackling the abuse of women fundamental human rights in Nigeria. The study relied on primary and secondary sources of information. It concludes by recommending that, for the full observance of human rights, an international control must be set up to supervise enforcement, as well as the education of the women and society in general.
\end{abstract}

Keys words: Fundamental Human Rights, Abuse, Panacea, Women, Nigeria.

\begin{abstract}
Abstrak
Ketentuan hak asasi manusia yang mendasar terus menonjol dengan sangat menonjol dalam konstitusi berturut-turut Republik Federal Nigeria. Selain itu, telah terjadi peningkatan dalam kegiatan kelompok hak asasi manusia di Nigeria untuk memastikan perlindungan hak asasi manusia yang fundamental bagi semua orang. Terlepas dari semua ini, pelanggaran mendasar hak asasi manusia wanita terus meningkat di Nigeria. Kasus kekerasan dalam rumah tangga, penculikan, pelecehan seksual, perdagangan perempuan, pembunuhan, penolakan hak atas pendidikan, dan lainlain adalah kejadian umum. Pelanggaran-pelanggaran ini antara lain bertanggung jawab atas keterbelakangan fisik dan psikologis perempuan dan anak perempuan yang pada gilirannya mempengaruhi masukan mereka dalam pembangunan bangsa mereka. Bertentangan dengan latar belakang ini, makalah ini mengkaji dua pelanggaran hak asasi manusia yang mendasar bagi perempuan: penyalahgunaan hak untuk hidup dan pendidikan. Makalah ini juga membahas peran penting dari penggunaan obat mujarab Islam yang efektif dalam menanggulangi pelecehan terhadap hak asasi perempuan di Nigeria. Studi ini mengandalkan sumber informasi primer dan sekunder. Ini menyimpulkan dengan merekomendasikan bahwa, untuk ketaatan penuh hak asasi manusia, kontrol
\end{abstract}

\footnotetext{
${ }^{1}$ Ige and Olumide Lewis, Human Rights Made Easy, (Lagos: TheNigeria Legal Research and Resource Development Center, 1999), p. 98
} 
Millatī, Journal of Islamic Studies and Humanities, Vol. 4, No. 1, Juni 2019: 99-116

internasional harus dibentuk untuk mengawasi penegakan hukum, serta pendidikan perempuan dan masyarakat pada umumnya.

Kata kunci: Hak Asasi Manusia Mendasar, Pelecehan, Panacea, Perempuan, Nigeria.

\section{INTRODUCTION}

The concept of human rights has become a global issue because of the realization of the role human right could play in the development of a society. A society is said to be good, when there are peace, freedom, justice and respect for human rights. Human rights refers to the relationship between the individuals and the state or its government; their rights to political participation, the freedoms that the individual should enjoy and their claims on the state as regards the provision of basic needs of life, education, health among others ${ }^{1}$.

In 1948, the General Assembly of the United Nations adopted and proclaimed the Universal Declaration of Human rights as the International Bill of Rights which is the most phenomenal document on the human rights regime to date. According to the United Nations Organization, these rights emphases that all people are created (born) equal and equally endowed with certain inalienable and inviolable rights because they are attached to the individual by reason of his or her humanity ${ }^{2}$. There is no doubt that the struggle for the preservation of rights has not been quite easy. This is true because, in every human society, there are people who prevent others from enjoying their human rights, such as denial of right to life, right to education, deterioration of standard of living of an average man etc. Thus, the recognition of these human rights is aimed at ensuring that each individual is accorded the freedom to exercise his/her fundamental human rights, so long as that freedom is not used to harm others.

This is why Islam, on the other hand, has established the concept of human rights since inception as a religion. It aims at ensuring equal rights of people of different races, color, language, as well as ideological and religious freedom for all nations of the world. Islam has laid down universal fundamental rights for all people which are to be observed in every circumstance. For example, human blood is sacred and may not be spilled without strong justification; it is not permissible to oppress women, children, old people, the sick or the wounded; women honor and chastity must be respected and so on ${ }^{3}$.

Babaji ${ }^{4}$ observes that many people in the world today have refused to appreciate the true status of women under the Shariah. In references to both the Qur'an and Hadith regarding the position of women in Islam. in the words of the Qur'an, “...And women shall have rights similar to

${ }^{2}$ Akpala, Ada, Sylvia, Women's Rights Are Human Rights, (Enugu: Snaap Press Ltd, 1998), p. 123

3 Abul A'lā Maudūdī, Human Rights in Islam, (London, Islamic Foundation, 1980), p. 90

${ }^{4}$ B. Babaji, Equity For Women Under Shari ah Law in Nigeria: A Comparative Study of the Law and Practice in Pakistan, Tunisia, and the Sudan, (Lagos: Gender and Development Action (GADA) ICON Communications, Constitutional Reform Debate, 2004), p. 26 
the rights against them according to what is equitable..." (Q2:228). In another place the Qur'an states:

\section{"O Mankind! Reverence your Guardian-Lord, Who create you from single Person, Created, of like nature, His mate, and from them twain scattered (like seeds) Countless men and women;- Reverence Allah, through Whom Ye demand your mutual (rights), And (reverence) the wombs (That bore you): for Allah Ever watches over you." (QS. 4:1)}

Again the Qur'an says: "From what is left by parents and those nearest related there is a share for women whether the property be small or large, - a determinate share".(Q4:7) etc. In addition, the teachings of the prophet $(S A W)$ have shown the high esteem for women in Islam. Many of his teachings underscore the need for Muslims to treat their parents kindly with the mother enjoying greater consideration Babaji ${ }^{5}$ notes that:

"Nigerian women who are Muslims have nothing to fear under the Sharids legal system as it has made adequate provisions for the protection of their rights....,".

Human rights are those "privileges which are claimed or enjoyed by a human being merely because he or she is human". Eze ${ }^{7}$ defines human rights as "demands or claims which individuals, a group makes on a society, some of which are protected by law and have become part of lexlata while others remain aspiration to be attained in the future". Ede ${ }^{8}$ believes that human rights are those rights inherent to man from his birth to his death. Maududi ${ }^{9}$ opines that human rights are sacred and must be protected. According to Wright, as stated by Yusuf these rights include the right of life,the right to an adequate standard of living, freedom from torture and other maltreatment freedom of religion and of expression, freedom of movement, the right to self-determination, the right to education, and the right to participation in cultural and political life ${ }^{10}$.

From these various points of view, fundamental human right can be explained as the basic universal inalienable social rights which should be enjoyed by all human beings regardless of their religion, race, ethnicity, gender and status. In other words, fundamental human right, are rights that belong to all as human beings and citizens of a country. Human rights are held to be inalienable and belong to all human and that is why rights are clearly written in the constitution of nations. They are necessary for freedom and rights to the maintenance of a reasonable quality of life. For instance, it

\footnotetext{
${ }^{5}$ Ibid.

. ${ }^{6}$ A.K. Damodaran, Protection of Human Rights.Atar Chard (ed) (Politics of Human Righ and Civil Liberties), (K.K. Thukal: UDH Publisher, 1985), p. 143

${ }^{7}$ Osita Eze, Human Rights in Africa: Selected Problems, (Lagos: Macmillan, 1984), p. 56. General's Daughter Lured from Nasarawa, Killed in Lagos ...wmw.thisdaylive.com accessed 27/11/2015. p. 89

${ }^{8}$ Ede, Angus, Arinze, Human Rights: Analytical perspective, (Enugu, Lagos, Abuja: Computer Edge Publishers, 2000),

${ }^{9}$ Abul A'lā Maudūdī, Human Rights in Islam, (London, Islamic Foundation, 1980), p. 90

10 Yusuf, "Issues in Fundamental Human Rights" - University of Ilorin www.uniilorin.edu.ng/publication/.../Issues. Accessed 30 ${ }^{\text {th }}$ November, 2015

${ }^{11}$ Ibid.

12 Rebecca Sako, Women Empowerment and Advancement Manual. (Kaduna, Nigeria: League of Democratic Women LEADS, 1999), p.13
} 
Millatī, Journal of Islamic Studies and Humanities, Vol. 4, No. 1, Juni 2019: 99-116

can be seen in the United States Constitution and French Declaration of Rights of Man and of the Citizen (1793) and the Nigeria constitution (1999) ${ }^{11}$.

Furthermore, many international instruments of human rights, which further reinforce individual rights also prohibit discrimination against specific groups, in particular women and children. The most important of these conventions is the Convention on the Elimination of All Forms of Discrimination Against Women (CEDAW). The Universal Declaration of Human Rights (UDHR), (1948) recognizes the political and civil rights; many countries have drawn their strength from this document. The rights in this Declaration are: the right to life and liberty, protection against arbitrary arrest, detention or exile. Others include: freedom of movement, the right to a fair trial, freedom of religion and conscience, the right to free and equal access to their franchise, and the right of citizens to participate in the government of their country ${ }^{12}$.

The International Covenant on Civil and Political Rights, which was adopted by the United Nations General Assembly in 1966 and took effect in 1973, further, broadened these rights. The African Charter on Human and Peoples' Rights (ACHPR) was adopted in June 1981 and was ratified by many countries, including Nigeria. It came into effect on $21^{\text {st }}$ October 1986 . It registered with the United Nations on $10^{\text {th }}$ September $1991^{13}$. As earlier mentioned, the African charter on human and peoples' rights came into force on $21^{\text {st }}$ October 1986 (African Charter). The Charter guarantees the right to life and it prohibits slavery as well as torture, cruel, inhuman or degrading treatment and punishment, it bars arbitrary arrest and detention.

It guarantees freedom of religion, the right to receive information, to express one's opinion, freedom of association and assembly, right to freedom, movement; and the charter prohibits mass expulsion of non-nationals, etc (Article 12 of the African Charter)..At a glance, the evolution of human rights can be found in the following documents, among others: Magna Charta, 1215; Petition of Rights, 1682; Bill of Rights, 1689; Virginia Declaration of Rights, 1776; American Declaration of Independence, 1776; French Declaration of Rights of Man and of the Citizen, 1789; Universal Declaration of Human rights, 1948; European Convention for the Protection of Human Rights and Freedom, 1950; American Convention for the Protection of Human Rights and Freedom, 1959; Written Constitutions for several independent modern states and states liberated from; and African Charter on Human and Peoples 'Rights,1986'.

\section{Fundamental Human Rights in Islam and the Nigerian Constitution}

The importance of human rights in Islam cannot be over-emphasized. In Islam, human rights are not restricted to any geographical area, people or place. For it is believed that human rights in Islam are a universal phenomenon. For this reason Islam has laid down some universal fundamental rights for humanity as a whole which must be respected under all circumstances. It should be noted that

\footnotetext{
${ }^{13}$ African Charter on Human and Peoples' Rights

14 O. Ojo Emmanuel, "Human Rights and Sustainable Democracy in Nigeria (1999 ...) www.krepublishers.com/.../JSS-13-1-015-029-2006-241-Ojo-Emmanuel. Accessed 20/11/15
} 
some of the human rights recognized in both national and international documents have been existing in Islamic tradition right from the lifetime of the Prophet (PBUH). These rights were fully guaranteed to the citizens of the first Islamic State of Madinah by the charter of liberty and reiterated by Muhammad in his farewell address.

In Islam, just as al-Maududi ${ }^{15}$ says, human rights in Islam, we mean rights granted to human beings by Allah, outlining the differences between the two given rights. He also pointed out that, while rights granted by kings and legislative assemblies can be withdrawn as easily as they are conferred, no individual and no institution has the power to withdraw the rights conferred by Allah. In addition, Allah's wisdom and foresight can never be compared with those of a man; that is the more reason why all that He has declared good remains good forever and what He had declared bad remains bad forever. Another difference is that human rights laws granted by humans are not spiritual, not compulsory on anybody, while those given by Allah form an integral part of Islamic faith. Therefore, whoever violates these rights will face the verdict of Allah.

From the explanations above, it follows that human rights are the rights sanctioned to humans by the Almighty Allah. These rights are rooted in the Islamic Law. It is the duty of every Muslim to recognize and enforce these human rights. If the administrators fail to enforce them, and start denying the rights that have been guaranteed by Allah or amend or change them, they are wrongdoers. Lawbreakers are those disregarding the bond of allegiance. Allah says:

"...And whoever judges not by what Allah has revealed, those are the disbelievers. And whoever judges not by what Allah has revealed, those are the wrong-doers. ... And whoever judges not by what Allah has revealed, those are the transgressors." (Qur'ān 5: 44, 45 and 47)

In the light of the present-day conditions, human rights from an Islamic point of view include the following: Right to Life; The Right to Property; Right to Human Dignity; The Right to Privacy; Right to Acquire Education; Security of Personal Freedom; Protection from Arbitrary Imprisonment; Right to Protest against Tyranny; Freedom of Expression; Freedom of Conscience and Conviction ${ }^{16}$.

In Nigeria, those rights that are considered fundamental to human beings are enshrined in Chapter IV of the 1999 Constitution of Federal Republic of Nigeria. These rights are — right to life - section 33, right to dignity of human person - section 34, right to personal liberty - Section 35 , right to fair hearing - section 36, right to private and family life, Section - 37, right to freedom of thought, conscience and religion - Section 38, right to freedom of expression and press - Section 39, right to peaceful assembly and association Section 40, right to freedom of movement section 41, right to freedom from discrimination - Section 42;and the right to acquire and own immovable property anywhere in Nigeria - Section $43^{17}$.

${ }^{15}$ Abul A'lā Maudūdī, Human Rights in Islam, (London, Islamic Foundation, 1980), p. 90

${ }^{16}$ Ibn Raji Abdul fatah, Islam and Human Rights in Broader Perspective. (Lagos: Jamiyyat Junud Dinil Islamiyyah, 2001), p. 76 
Millatī, Journal of Islamic Studies and Humanities, Vol. 4, No. 1, Juni 2019: 99-116

It is interesting to note that what the Nigerian constitution as well as other legal documents recognize as fundamental human rights has been given to humans by Islam irrespective of gender over fourteen centuries ago. Therefore, in order to fight against the phenomena of women human rights violations an introduction of major normative and attitudinal changes and restoration of moral and spiritual values is essential. Justice, equality, development and peace for women or for men cannot be achieved unless measures are taken to commit oneself to respect and love of every human life at every stage and in every situation.

\section{Procedure for the Enforcement of Human Rights}

There are processes used for the enforcement of human rights at the national, regional and international levels. Provisions have been made in the Nigerian constitution, African Charter on Human and People's Rights as well as the universal declaration of human rights. According to the Nigerian constitution, one can get access to an ordinary court through application for enforcement of guaranteed rights. For instance, section 46(1) of the 1999 constitution provides that: "Any person who alleges that any of the provisions of this chapter has been is being or likely to be contravened in any state in relation to him may apply to a high court in that state for redress".

Section (2) further provides:

"A high court shall have original jurisdiction to hear and determine any application made to it in pursuit of the provisions of this section and may give such direction as it may consider appropriate for the purpose of enforcing or securing the enforcement within that state of any rights to which the person who makes the application may be entitled under this chapter."

Apart from the process of enforcement through the court, the national Human Rights Commission plays a vital role in this respect. This was established by the Federal Military Government and was inaugurated in $1996^{18}$.

Since its establishment, the National Human Rights Commission in Nigeria has worked in areas such as; investigation of complaints, public enlightenment and education, mediation and reconciliation, conflict resolution, peace-building, research advocacy and training programs on contemporary issues in the field of human rights. Among its activities was the establishment of the National Action Plan (NAP) on human rights as a mark of government's commitment to the promotion and protection of human rights. The $N A P$ is expected to be a benchmark against which Nigeria's human rights records can be judged ${ }^{19}$.

${ }_{18}$ M. Tabiu, "The Role of the National Human Rights Commission in the Promotion and Protection of Human Rights" paper presented at a 2 day Workshop for non-governmental organizations (NGOs) and Journalists in NorthEastern Zone organized by the National Human Rights Commission in collaboration with the Network for Justice (NJ) at Zaranda Hotel, Bauchi, from 14 ${ }^{\text {th }}-15^{\text {th }}$ December 1999.

19 “About Us", National Human Rights Commission, (Abuja: Nigeria, n.p.n.d), 
The enforcement framework of the substantive provisions of the African Charter is contained in part II, which is named, "Measures of safeguard". It is made up of four chapters. Chapter 1 deals with the establishment and organizational structure of the commission, while chapter 2 is on the mandate of the commission. Chapter 3 is premised on the procedure of the commission, whereas chapter 4 relates to principles which are applicable to the commission ${ }^{20}$.

It is worthy of note that the Fundamental Human Rights provisions exist in the constitutions of the Federal Republic of Nigeria. In addition, there are increase activities of different Human Right groups in Nigeria with the sole aim of protecting the Fundamental Human Rights of all people. Despite these efforts, women Fundamental Human Rights abuse is on the increase in Nigeria. Such abuse includes among others, domestic violence, kidnapping, sexual harassment, killings and denial of the right to Education. These abuses have negative impact on physical and psychological development of women and girl child.The objective of this paper therefore, is to examined two abuses of women fundamental human rights. They are; abuse of right to life and education. The paper shows the importance of Islamic Shari'ab and how it can be used to tackle the abuse of women fundamental human rights in Nigeria. The study used both primary and secondary sources of information.

\section{RESULT AND DISCUSSION}

\section{Examination of Two Cases of Women Rights Violation in Nigeria}

Women in Nigeria face various versions of human rights violations despite the provisions provided to them in the 1999 Constitution. Furthermore, women in Nigeria do not always utilize the opportunity provided to take up unconstitutionality to higher courts and as such, there continues to be many violations occurring. The following are the two cases of women rights violation in Nigeria. Firstly is the denial of right to life. It is one of the areas where women rights are violated in Nigeria today. For instance, nine female polio vaccinated were killed by unknown gunmen in 2013 at different center in Kano State. The gunmen opened fire on a health center at Hotoro, killing seven health workers, while the attack that occurred at the Zaria Road area of the city claimed additional two lives ${ }^{21}$. Another case of denial of right to life was that of Late Cynthia Udoka Osokogu who until her death was running a postgraduate program in Public Administration at the Nasarawa State University, was lured to Lagos by a group of men whose stock-in-trade is to lure young girls and kill them after dispossessing them of their belongings. She was killed on July 22, 2012 in an hotel in FESTAC. A police source said the culprits belong to a syndicate that specialized in luring young women to Lagos for the purpose of business only to kill them ${ }^{22}$.

There was also the case of one Gbenga who beat his wife, Sherifatu to death and after that tied a wire around her neck and hanged her on the ceiling ${ }^{23}$. The incident occurred on Monday,

\footnotetext{
${ }^{20}$ The African Charter, Part I, part ii, Part iii, \& part iv

${ }^{21}$ Gunmen kill 9 Polio Vaccinators in Kano Gunmen www.naij.com > Local News Accessed 26/11/2015.

${ }^{22}$ General's Daughter Lured from Nasarawa, Killed in Lagos ...wmw.thisdaylive.com Accessed 27/11/2015

${ }^{23}$ Chukwuma, "Shart ah and BariyaMagazu", Violence Watch, October - December 2000.
} 
Millatī, Journal of Islamic Studies and Humanities, Vol. 4, No. 1, Juni 2019: 99-116

September 4, 2000. Sherifatu, mother of two, was said to have been having problems with her husband, Gbenga Illesanmi who was claimed to be a herbalist and involved in advance fee fraud popularly referred to as 419. It was reported that Gbenga had beaten his wife on several occasions and at last beat her to death ${ }^{24}$.

Another case is the one reported in the news page weekly edition of July 18-24 2008 which reads "Re: inheritance of spouses in Islam". The report is about a Muslim husband who had a wealthier and more educated Muslim wife. She had a terminal ailment, which he prevailed upon her not to disclose to members of her extended family. He also encouraged her to defy medical advice by becoming pregnant, which was fatal; and when she lay helplessly ill, he refused her access to medical attention till she died. Thereafter, he went to court to demand his right to inheritance ${ }^{25}$. Another incident is reported in the Punch Newspaper of December, 30 ${ }^{\text {th }}$, 2008. According to the report, Saheed requested for sex from his wife Kafaya who turned down the request on the grounds that she had just delivered a baby two months earlier. It was learned that the man picked a knife and stabbed the wife and the baby to death ${ }^{26}$.

There is also the case of a 55-year-old man in Kano, Mallam Alhassan Katsina, who was arrested by the police for impregnating his daughters (Hadizah and Bilkisu) and killing Bilkisu's baby after its delivery. The report states that this was the third time such an incident occurred. The first time was with his first daughter, Hadizah whose pregnancy was aborted by her father who had impregnated her. She later developed some complications and died. The second time was with his sister's daughter and the third is this incident involving Bilkisu, who is his daughter too ${ }^{27}$. These actions and many others prove that people no longer respect the international declaration of human rights. It is vital for every human being to know that, under no circumstance should he or she be guilty of taking a human life. The Glorious Qur'an expressly states: “...if anyone slew a person unless it be for murder or for spreading mischief in the land it would be as if he slew the whole people...." (Qur’ān5: 35).

On the issue of homicide, the prophet of Islam has declared it as the greatest sin only next to polytheism. He says: "The greatest sins are to associate something with Allah and to kill human beings" 28 . This injunction applies to all human beings and the destruction of human life in itself has been prohibited. Thus, women like men have the right to live on earth. Immediately after the verse of the Qur'an which has been mentioned in connection with the right to life, Allah said further: “.... and if anyone saved a life it would be as if he saved the life of the whole people..." (Qur'ān. $5: 35)$.

${ }^{24}$ Chukwuma (2000); "Shart ah and BariyaMagazu" Violence Watch October - December 2000.

25 Al-Bishak, "Re-Inheritance of Spouses in Islam”, Newspage Weekly, July 24-18-2008

26 O. Ojo Emmanuel, "Human Rights and Sustainable Democracy in Nigeria (1999 ...) www.krepublishers.com/.../JSS-13-1-015-029-2006-241-Ojo-Emmanuel. Accessed 20/11/15

${ }^{27}$ Mūsā Nūḥu Jamīlah, "Man Makes Underaged Daughter Pregnant Kill Baby at Birth”, Kano Trust, Tuesday, November 25, 2003.

${ }^{28}$ Adh-Dhahabi Shamsudeen, (n.d.); Al-kabäirr, (Beirut: Dār al Fikr, n.p.n.d), p. 96

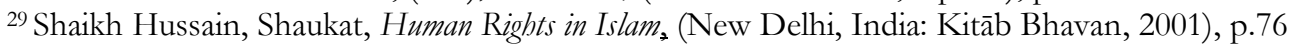


Thus, under the Shariah, no one has the right to take the life of another person without just cause i.e. due process of law. (Qur'ān 17:33). In that case, it is decided by a proper and competent court of law. The practice nowadays is that people usually take lives of others without any genuine reason.

One of the factors which have become a great hurdle in the enforcement of human rights could be the international declaration of human rights which recommends that a country is free to follow or defy these declarations after it has been signed. As such no action is taken against any country for the violation of human rights. Another problem facing the enforcement of human rights is the fact that the society and especially, women are ignorant of the fundamental human rights. This concern was expressed during the international conference on the rights of women which took place at Kabul in the year $1952^{29}$. Therefore, for the full observance of human rights, an international control must be set up to supervise enforcement, as well as the education of the women and society in general. However, there is still room for finding lasting solutions to the enforcement of human rights, especially by all the countries that have ratified it.

The goal of any developing country (like Nigeria) is to protect and preserve the fundamental human rights of her citizens. Therefore, as long as the judiciary is interested in the development and enjoyment of human rights, it cannot afford to close its eyes to human rights violations by any person or group. It has the responsibility to see that these rights are promoted and protected. In Islam, Human Rights are an important concept that must be respected. Violating it is a sign of disobedience to Sharidh, and above all, to Allah. The first among the basic human rights granted by Islam is the right to and respect for human life. During the farewell pilgrimage, in his address, the Prophet Muhammad (SAW) is reported to have said: "Your blood, your property and your honor are as sacred as this city (i.e. Makkah and the surrounding area") ${ }^{30}$.

Islam enjoins Muslims to respect this right even for the child within the womb of his mother. The Prophet postponed the capital punishment of a woman for protection of the right of life of the child within her womb ${ }^{31}$. In essence, the security of life has been given to man by Islam, to safeguard it. Islam has laid down the cases and situations where human life can be destroyed, for instance, retaliation for murder (Qur'ān 2: 178). Therefore, in an Islamic state, the lives and properties of human beings must not be tampered with, except in situations approved by Islam.

Secondly is the denial of the right to acquire education. Islam encourages the pursuit of knowledge by all Muslims regardless of their sex. In fact, the search for knowledge is the first thing the prophet of Islam was commanded to do. This is clearly indicated in the Qur'an: "Proclaim! (or Read!) in the name of thy Lord and Cherisher Who created. Created man out of a (mere) clot of congealed blood: Proclaim! And thy Lord is Most Bountiful. He who taught (the use of) the Pen. Taught man that which he knew not" (Q 96:1-5).

${ }^{30}$ Muhammad Hussayn Haykal. The life of Muhammad, translated by Ismail Kagi A. al-Faruqi, (Nigeria: Academy, n.d.), p. 56

31 Ibn Ismā'îl Muḥammad Al-Bukhārī, Saḥị̣ al-Bukhārī, (Arabic-English), Vol. 8, (Arabiya: Dār-al-Arabia, n.d.), p. 858 
Millatī, Journal of Islamic Studies and Humanities, Vol. 4, No. 1, Juni 2019: 99-116

The verses above show the importance of knowledge not just to the prophet but to the generality of the people regardless of sex. Some parents in Northern Nigeria display a Luke-warm attitude towards the education of their female children. This practice is repugnant to the principles of Islam. They are made to believe that their education is not important and that the western education is a waste and irrelevant to their well being. This negative attitude already instilled in the girls does not make them perform well academically even when they have the opportunities of going to school. Home helpers syndrome is another practice that denies the girl -child her right to education. This happens when the male member cannot discharge his financial responsibility on his family. The girls mostly from rural areas are taken to cities in order to offer domestic services, in private households for an agreed amount of money.

One of the major challenges of girl child education is the poor or little knowledge of Islam among Muslims in rural areas. Some parents in Northern Nigeria (rural areas especially) are not aware of the Islamic injunction to seek for knowledge and so does not support majority of their girls to acquire Islamic education.

Another challenge that militates against girls' education especially among rural communities of Northern Nigeria is the high incidence of poverty. Halimat Jibril mentioned that the "Action Aid stated that poverty in the region is estimated at an average of $70 \%$ as compared to $34.93 \%$ for the southern states (121)". These factors constitute a major hindrance to girls' transition in our schools.

Addressing journalists at the "Day of the African Child" with the theme: "A child friendly, quality, free and compulsory education for all children in Africa,' in Bauchi, the organization Planning Monitoring and Evaluation Specialist, Dr. Danjuma Almustafa, who represented Dr. Abdulai Kaikai, the Chief of Field Office, UNICEF Bauchi, lamented that, "even when enrolled, hundreds of children - especially girls - are not showing up for classes. Although girls' primary school attendance has generally been improving, this has not been the case for girls from the poorest households. "Rural areas are disadvantaged almost everywhere in the country". Meanwhile, the former Minister of Women Affairs and Social Development, Hajiya Zainab Maina, has admitted that the abduction of the Chibok school girls has drawn the nation back on efforts and strategies to promote the child education. Represented by the Director of Legal Affairs in the ministry, Mrs. Victoria Eze-Igwe, at the commemoration of the Day of the African Child in Abuja, the Minister gave the assurance that the Federal government was working to ensure that the girls are safely returned to their parents ${ }^{33}$.

Maina added that girl-child education would continue to be accorded priority attention to reduce the incidence of early marriage and its attendant complications such as Vesico Vagina Fistula (VVF), and maternal and infant mortality rates ${ }^{34}$. Although the practice of denying the girl child education is gradually being eradicated its existence still warrants considerable attention because it

\footnotetext{
${ }^{32}$ Lara Adejoro, “10.5 Million Nigeria Children Out of School, Says Boko Haram Is A Setback” June $17^{\text {th }} 2014$ bttps:/ / wmw.dailytrust.com.ng/ Accessed $24^{\text {th }} / 11 / 15$.

${ }^{33}$ Lara Adejoro, "10.5 Million Nigeria Children Out of School, Says Boko Haram Is A Setback" June $17^{\text {th }} 2014$ bttps:// wmw.dailytrust.com.ng/ Accessed $24^{\text {th }} / 11 / 15$.
} 
affects attitudes and behavior to the issue of development. Therefore, the fact still remains that we need more female doctors, pharmacists, engineers, lecturers, bankers, editors, writers, women scholars especially in the knowledge of Qur'ān to be able to read, translate and interpret Qur'anic injunctions.

\section{Islamic Panacea to Abuses of Women Human Rights in Nigeria.}

To address the problems of women rights violations, the following suggestions are proffered towards an effective application of the Islamic provisions for the rights of Muslim women in Nigeria. First is the awareness programs in which focus should be put on awareness programs in order to inform women of their rights, to enable them link rights given to them under Islamic law (Shari'ah) with those existing under International Instruments and to highlight compatibility between Islamic legislation and International law.

Second is Allah-consciousness. In addition to the above enunciation, Islam lays great emphasis on creating Allah-consciousness in people's minds. Allah-consciousness (Taqwallah) breeds His fear and righteousness. One who is Allah-conscious and righteous will, both in public and in private, act rightly even in the absence of law enforcement agents. Such person will not do anything that could undermine the fundamental human rights of other individuals and the nation at large. To stem the tide of women fundamental human rights violations in Nigeria, attention should be shifted from the materialistic tendency that is one bane of the nation to the emphasis on religion and morality. The apparent failure to prevent women human rights violations despite all efforts denotes that the problems with Nigerians are moral and integrity diseases which could only be cured through divine intervention. The Glorious Qur'ān says: "Truly, it is not the eyes that are blind, but blind are the hearts which are in the breasts". (Qur'ān 22:46). The word "heart" in Arabic denotes the seat of intelligence, faculties and understanding as well as the seat of affections and emotions. Those who are involved in violating the human rights of women may have their physical eyes and ears, but their hearts are blind and deaf. There is therefore the serious need for a spiritual rebirth and information which must go beyond mere cosmetic and artificial re-branding. The rebirth must be all embracing; cutting across all strata of the entire citizenry-the leaders and the led.

Third is the campaign through admonition and guidance and counseling ( $\left.D a^{c} w a b\right)$. Most Nigerians are religious. Those who engage in violating the rights of women in the society are either mosque or church goers. In addition, scholars, both Muslims and Christians are closer to the people. Effective preaching of Allah's Words which in Islamic parlance is known as da'wah could also be used to tackle the problem of women rights violation in the country. Apart from the emphasis on the worship of Allah, campaigns through admonition and guidance and counseling could also be mounted to address other social problems such as murder, rape, killing, robbery, kidnapping, etc. Through such efforts, criminals might turn on leaf and eschew criminal acts.

${ }^{34}$ Lara Adejoro, "10.5 Million Nigeria Children Out of School, Says Boko Haram Is A Setback” June $17^{\text {th }} 2014$ bttps:/ / wmw.dailytrust.com.ng/ Accessed 24th / 11/15. 
Millatī, Journal of Islamic Studies and Humanities, Vol. 4, No. 1, Juni 2019: 99-116

Forth is Justice of Islam, recognizing the fact that protection of individual rights will be elusive in a society where there is injustice, it therefore lays great emphasis on justice and fair play. The implication of this is that no section should be marginalized or treated as second class citizen. In this regard, Al-Qur'an admonishes thus: "let not the hatred of others make you swerve to wrong and depart from justice” (Qur'ān 5:8).

Fifth is the welfare which closely related to the above point is the issue of welfare. A nation that fails to pay serious attention to the above point on the issue of welfare of its citizenry or only pays lips service to it cannot enjoy peace and security. That is because some people, in order to make ends meet, will take to criminal acts and devilry such as robbery, killing, kidnapping, etc. and become a security threat to the society. If only those in authority in Nigeria would take to the teachings of Islam, the nation would be better for it This welfare lies in complete justice, mercy and provision of at least, basic amenities such as housing, good roads, potable water, health care delivery, light, education etc. Thus, promoting the welfare of the people lies in safeguarding their fundamental human rights.

Sixth is the Implementation of Capital Punishment. Another Islamic panacea is implementation of capital punishment called hadd (pl. huudüd) for crimes. Under the Sharí' ah, certain capital punishments are stipulated for some categories of heinous crimes chiefly to serve as deterrent for potential criminals. Though, seriously criticized especially by Human Right activists, the truth which cannot be controverted are Islamic countries such as Saudi-Arabia has been able to reduce crime and insecurity to the barest minimum largely as a result of the implementation of capital punishment.It should, however, be noted that hadd is introduced and applied only after the Government has adequately provided for the basic needs of its citizenry.

\section{CONCLUSION}

The study reveals that there are many negative practices prevalent in Nigeria which affect the rights of women in general and Muslim women in particular. The study finds out that, Islam has revolutionized the rights of women for the first time in the history of world civilization by giving women all their rights. Against this background, the Convention on the Elimination of All Forms of Discrimination Against Women (CEDAW) which was ratified by the United Nations General Assembly resolution of December 1979 indicated earlier is a prototype of what Islam has already given women since the advent of the religion. Thus, massive enlightenment campaigns should be embarked upon to educate the people on the Shari'ah, its attitude towards gender equality and the rights of all Human Beings. Husbands must stick to the procedures of settling disputes as outlined in the Sharíah particularly according to Qur'ān 4:34, where steps for corrections are laid down. Spousal abuse and divorce are injurious to Muslim societies because people end up with unhappy and broken homes where children end up suffering the consequences.The various Islamic groups should organize seminars, workshop, etc. to educate the people so that they know their rights and are capable of analyzing issues and making balanced judgments on Shariah. For the full observance of human rights, an international control must be set up to supervise enforcement, as well as the education of the women and society in general.The campaign of awareness by both government and 
religious leaders on the importance of female education should be intensified until such a time when people realize the importance of female roles in the hospitals, schools, banks, oil companies and other service areas.

\section{REFERENCE}

“About Us" (n.p.n.d) National Human Rights Commission 2 Abuja: Nigeria.

Adh-DhahabiShamsudeen (n.d.); Al-kabāìr, Beirut Dār al Fikr.

A. Yusuf (2015); "Issues in Fundamental Human Rights" - University of Ilorin www.unilorin.edu.ng/publications/.../ISSUES.pdfAccessed 30th November, 2000.

Al-Bishak 'Re-Inheritance of Spouses in Islam ”NewspageWeekly,July 24-18-2008

Al-Bukhārī, Ibn IsmāîilMuḥammad (n.d.); Sạ̣ị̣ al-Bukhārī (Arabic-English) Vol. 8, Dār-al-Arabia:

Akpala, Ada, Sylvia (1998); Women's Rights Are Human Rights, Enugu: Snaap Press Ltd.

Babaji, B. (2004) Equity For Women Under Shari ah Law in Nigeria: A Comparative Study of the Law and Practice in Pakistan, Tunisia, and the Sudan. Lagos: Gender and Development Action (GADA) ICON Communications, Constitutional Reform Debate.

Badawi, Jamal(1996) "Position of Woman in Islam” The Muslim WorldLeague Journal, Vol. 23.

Chukwuma (2000); "Shariah and BariyaMagazu” Violence Watch October - December 2000.

Damodaran, A.K. (1985); Protection of Human Rights.Atar Chard (ed) (Politics of Human Righ and Civil Liberties). K.K. Thukal: UDH Publisher.

Ede, Angus, Arinze (2000) Human Rights: Analytical perspective. Enugu, Lagos,Abuja: Computer Edge Publishers.

Eze, Osita(1984); Human Rights in Africa: Selected Problems, Lagos: Macmillan,General's Daughter Lured from Nasarawa, Killed in Lagos ....mwn.thisdaylive.comaccessed 27/11/2015.

Gunmen kill 9 Polio Vaccinators in Kano Gunmen ...www.naij.com > Local news accessed 26/11/2015.

Hussain, Shaikh (2001); Shaukat. Human Rights in Islam, New Delhi, India: Kitāb Bhavan.

Ibn Raji Abdul fatah (2001) Islam and Human Rights in Broader Perspective ${ }_{2}$ Lagos:

JamiyyatJunudDinil-Islamiyyah.

Ige, Tokunbo. and Olumide Lewis (1999). Human Rights made easy. Lagos: The

Nigeria Legal Research and Resource Development Center.

Lara Adejoro (2014); “10.5 Million Nigeria Children Out of School, Says Boko Haram Is A Setback". June $17^{\text {th }} 2014$ https:// www.dailytrust.com.ng/ accessed $24^{\text {th }} / 11 / 15$.

Maudūdī. Abul A'lā (1980); Human Rights in Islam. London, Islamic Foundation.

Maudūdī. Abul A'lāIntroduction to Surahal-Aḥābhittp:/ / www/ usc.edu/dept-MSA/quranEncyclopaedia 
Millatī, Journal of Islamic Studies and Humanities, Vol. 4, No. 1, Juni 2019: 99-116

America Vol. 29,108. Accessed when?

MūsāNūḥuJamīlah (2003); "man makes underaged daughter pregnant kill baby at birth".

Kano Trust, Tuesday, November 25.

Ojo Emmanuel O. "Human Rights and Sustainable Democracy in Nigeria (1999 ...)"

www.kepepublishers.com/.../JSS-13-1-015-029-2006-241-Ojo-Emmanuel...Accessed 20/11/15

Sako, Rebecca (1999);.Women Empowerment and Advancement Manual. Kaduna, Nigeria: League of Democratic Women (LEADS).

Tabiu, M.(1999); "The Role of the National Human Rights Commission in the Promotion and Protection of Human Rights" paper presented at a 2 day Workshop for non-governmental organizations (NGOs) and Journalists in North-Eastern Zone organized by the National Human Rights Commission in collaboration with the Network for Justice (NJ) at Zaranda Hotel, Bauchi, from $14^{\text {th }}-15^{\text {th }}$ December. 